\title{
Sınıf Öğretmeni Yetiştirme Sürecinde Problem Çözmeye Dair Pedagojik Alan Bilgisine İlişkin Çıkarımlar
}

\author{
Inferences on the Pedagogical Content Knowledge in the \\ Context of Problem Solving in the Process of Classroom \\ Teacher Training
}

\begin{abstract}
Ebru AYLAR*
Öz: Problem çözme becerisi, son yıllarda matematik öğretimi içerisinde ağırlığı artan bir beceridir. Problem çözme geliştirilebilir bir beceri olarak görülmenin ötesinde matematik öğrenmenin önemli bir aracı haline gelmiştir. Öğrencilerin matematiği daha etkin öğrenmeleri ve problem çözme becerilerinin gelişimi açısından öğretmenlerin problem çözmeye dair pedagojik alan bilgileri önem taşımaktadır. $\mathrm{Bu}$ çalışmada, sınıf öğretmeni adaylarının problem çözmeye dair pedagojik alan bilgileri önce teorik, sonra uygulama düzeyinde incelenmiştir. Araştırma 4. sınıfa devam eden 17 sınıf öğretmeni adayı ile gerçekleştirilmiştir. Bir durum çalışması olarak gerçekleştirilen bu araştırmada veri toplama araçları olarak sınıf öğretmeni adaylarının sınıf öğretmenine dair kendi gerçekleştirdikleri gözlemleri, onların ders anlatımlarına ilişkin araştırmacı gözlemi ve onlarla gerçekleştirilen yarı yapılandırılmış görüşme kullanılmıştır. Elde edilen tüm bulgular öğretmen yetiştirme programının yeterlikleri bağlamında tartışılmış ve Polya'nın problem çözme basamaklarını içeren temalar altında sunulmuştur. Öğretmen adaylarının \% 29'unda problem çözmeye dair güncel bir pedagojik alan bilgisinin varlığı gözlenememiştir. Geri kalan öğretmen adaylarının problem çözmeye dayalı bir derse ilişkin teorik bilgileri ile uygulamaları arasında da ciddi bir fark gözlenmiştir. Öğretmen adaylarının görüşlerine dayanarak bu sorunun öğretmen yetiştirme sürecinde uygulama ve teori arasında kurulan zayıf bağdan kaynaklandığı söylenebilir.

Anahtar Kelimeler: Problem çözme ile öğretim, problem çözmeye dair pedagojik alan bilgisi, sınıf öğretmeni adayları
\end{abstract}

\begin{abstract}
Problem solving is one of the main topic whose importance has been increased in mathematics education recently. Problem solving has become an important tool in learning mathematics beyond being seen as an enhanceable skill. The role of the teacher in this teaching process is important for the development of student problem-solving skills and the effective learning. Prospective primary teachers pedagogical content knowledge in the context of problem solving in theory and practice is examined in this research. The research was conducted with 17 fourth year prospective classroom teachers. It is a case study, and observations of prospective primary teachers towards school teachers, observations of researchers towards prospective teachers lectures and semi-structured interviews were used as data collection tools. All findings are discussed in the context of the competencies of the teacher training programs and presented under the themes including the Polya's problem solving steps. Any current pedagogical content knowledge in the context of problem solving was observed on $29 \%$ of prospective teachers. Moreover, that there was a serious difference between the theoretical knowledge and their teaching practice of the remaining prospective teachers on problem solving. Based on the opinions of the prospective primary teachers, it can be said that this problem is caused by the weak connection between the practical and theoretical courses in teacher training programmes.

Keywords: Teaching through problem solving, pedagogical content knowledge in the context of problem solving, prospectice primary teachers
\end{abstract}




\section{Giriş}

Problem çözme matematik eğitimi alanındaki ağırlığı ve önemi yakın bir dönemde artan bir başliktır. Dünyada gerçekleşen pek çok eğitim reformunda olduğu gibi Türkiye' deki program değişikliklerinde de problem çözmeye daha fazla önem verilmeye başlanmıştır. Problem çözme, ilkokul matematik dersi öğretim programında geliştirilmesi gereken temel matematik becerilerinden birisi olarak ele alınırken, "matematiksel bir bilginin pekiştirilmesi kadar, matematiksel bilgiyi genişleten ve derinleştiren, anlamlı bir öğrenme süreci” olarak ifade edilmektedir (Milli Eğitim Bakanlığg [MEB], 2015, s.6).

$\mathrm{Bu}$ yaklaşım son 20 yılı aşkın süredir dünya ölçeğinde yaygınlık kazanan problem çözmeye ilişkin yaklaşımlarla paraleldir. Matematik eğitimi alanındaki standartların belirlenmesinde önemli bir role sahip olan National Council of Teachers of Mathematics'in (NCTM) 2000 yılında yayımladığ "Principles and Standards for School Mathematics" raporunda problem çözme matematik öğrenmenin sadece bir amacı olarak değil, aynı zamanda matematik öğrenmenin temel aracı olarak da ele alınır. Rapora göre okul öncesinden lise son sinıfa kadar tüm öğrenciler;

- Yeni bilgileri, baştan sona problem çözmeyle inşa edebilmeli;

- Matematik ve diğer bağlamlarda görünen problemleri çözebilmeli;

- Problem çözmek için çok çeşitli uygun stratejileri uygulayabilmeli ve bu stratejileri uyarlayabilmeli;

- Problem çözme sürecini izleyebilmeli ve yansıtabilmelidir.

Matematik öğretiminin bir amac1, aracı ve öğrenme süreci olarak betimlenen problem çözme, matematik öğretimi ile üç bağlamda ilişkilendirilebilir (Schroeder ve Lester, 1989); problem çözme için öğretim, problem çözme öğretimi ve problem çözme ile öğretim. Geleneksel bir yaklaşım sunan problem çözme için öğretimde öğretim gerçekleştikten sonra problem çözülür. Önce öğrenciye bir becerinin gelişimine yönelik öğretim uygulanır, sonra öğrencinin edindiği bu beceri ile problemi çözmesi beklenir. Problem çözme öğretimi ise problemin nasıl çözüleceğinin öğretimidir. Problem çözme için öğretimin tersi olarak ele alınabilecek problem çözme ile öğretim ise güncel/çağdaş bir yaklaşım sunmakta, öğrenmenin gerçek bağlamlar, modeller, durumlar ve problemler aracılığıyla gerçekleştiğini belirtmektedir. $\mathrm{Bu}$ yaklaşıma göre beceriler problem çözme sürecinde ortaya çıkar, öğrenme problem çözme ile gerçekleşir.

Geleneksel olan problem çözme için öğretim ile güncel/çağdaş olan problem çözme ile öğretim yaklaşımları karşımıza iki ayrı öğretmen rolü çıkarmaktadır. Pek çoğumuzun kendi öğrencilik deneyiminden anımsayacağı problem çözme için öğretim yaklaşımında öğretmen merkezdedir ve herhangi bir üniteye öğretmenin bilgileri sunuş yolu ile aktarımıyla başlanır. Tüm bilgilerin sunulmasının ardından problem çözmeye geçilir. Problem çözme etkinliği sonuç odaklıdır ve amaç doğru sonuca ulaşmaktır. Bu nedenle, öğrencileri doğru sonuca ulaştıran bilgi ve tartışmalar daha önemlidir. Problem çözme ile öğretim ise öğrenci merkezlidir. Öğrencinin daha yoğun bir şekilde problem çözme etkinliğine katıldığı bu yaklaşım doğru sonuca odaklanmaktan ziyade, bireyi doğru sonuca ulaştıran sürece odaklanır. Öğrencinin problemle karşılaştığı ilk andan, çözüme ulaşıp çözümün doğruluğundan emin olduğu ana kadar olan tüm süreç problem çözme etkinliği olarak değerlendirilir. Bu güncel yaklaşımla problem çözme, işlenilen konunun sonunda, konu anlatımının hemen ardından ele alınan bir soru çözme aktivitesi olmanın çok ötesine geçmiştir. Artık problem çözme, öğrenme sürecinin önemli bir bileşeni olarak, tüm matematik konularına entegre edilmesi önerilen, öğrenmenin gerçekleştiği anlar olarak ele alınmaktadır. Bu yaklaşım geleneksel, öğretmen merkezli ders izlencesinden çok farklı bir sınıf içi aktivite gerektirmektedir. Bu aktivite sürecinde öğretmenin rolü, öğrencide problem çözme becerisinin gelişimi açısından önemlidir.

Bugün literatürde problem çözmeye ilişkin pek çok çalışmaya rastlanmaktadır ve bu çalışmaların önemli bir kısmı Polya'nın (1973) problemi anlamak, çözüm stratejisi geliştirmek, çözümü uygulamak ve kontrol şeklinde sıralanan aşamalandırmasını temel almaktadır. Analitik düşünme sitilini temel alan bu yaklaşımın bugün en yaygın kabulü alarak, öğretim planlarının 
içerisine girmiş olması bu stratejinin basit, doğrusal ve kulağa doğru gelmesinden veya çoğu kişinin problem çözerken az ya da çok bu basamakları gerçekleştiriyor olmasından kaynaklanıyor olabilir (Bodner, 1987; Stice, 2007). Günümüzde, eğer problem çözmeye öğretim süreci içerisinde merkezi bir rol atfedecek olursak, öğretmenler açısından problem çözme ile öğretim ve Polya'nın problem çözme yaklaşımı bilgilerine bir arada sahip olmak ve bu ikisini harmanlayabilme becerisi önem kazanmış bulunmaktadır.

Aslında problem çözme ile öğretim sürecini öğrenci, öğretmen ve program saç ayağına dayandırmak mümkündür. Torp ve Sage (2002) probleme dayalı öğretimin bu üç ana öğesinden şu şekilde bahseder; öğrenci verilen problemi sahiplenmeli (problemler öğrencinin ilgisini çekebilmeli), müfredat probleme dayalı yapılandırılmalı ve öğretmen öğrencinin aktif olacăğ, düşünme becerilerinin gelişeceği bir öğrenme ortamı yaratabilmeli. Öğrenciler için ilginç bir durum içeren problemler onları problemle uğraşmaları için motive eder. Öğrencilerin ilgisini çekebilecek problemler seçmek, bu problemlerle ilgili çözüm yollarını çeşitlendirebilmek, programın veya ders kitaplarının problem çözmeye ilişkin içeriğindeki eksikleri giderecek kurgular üretebilmek ve öğrencinin aktif olduğu bir öğrenme ortamı yaratabilmek bağlamında öğretmen faktörü, problem çözme ile öğretim yaklaşımında önemli bir faktördür. Yani öğretmenin problem çözmeye dair pedagojik alan bilgisinin yeterliği de problem çözme ile öğretim yaklaşımı açısından önemlidir.

Öğretmen yeterliğinin öğrencilerin öğrenmelerinde önemli rol oynadığı bilinmektedir (Çakan, 2004; Demir ve Bozkurt, 2011). Öğretmenin pedagojik alan ve alan bilgilerinin etkili bir öğretim gerçekleştirebilmelerinde önemli olduğu da birçok çalışmada vurgulanmıştır (Ball, 1990; Hill, Rowan ve Ball, 2005; Shulman, 1987). Öğretmenlerin bu yeterliliklerinin gelişiminde lisans eğitimlerinin oluşturacağ zemin önemlidir. $\mathrm{Bu}$ nedenle öğretmenlerin problem çözmeye ilişkin pedagojik alan bilgilerinin gelişimi, öğretmen yetiştirme programlarında dikkate alınması, önemsenmesi gereken bir yeterliktir. Pedagojik Alan Bilgisi (PAB) içerik bilgisini, o içeriğin nasıl öğretileceğinin bilgisini ve bu içeriğin öğrenim ve öğretimi ile ilgili eğitimsel konuları birleştiren bilgidir. Pedagojik alan bilgisi gelişkin olan bir öğretmen o konuya ilişkin bilgisini öğrenenin rahat algılayıp, edinebileceği bilgiye dönüştürebilen öğretmendir (Saeli, Perrent ve Jochens Zwaneveld, 2011). Problem çözme ile öğretim yaklaşımında edinilmesi gereken problem çözmeye dair PAB ise sonuca değil sürece odaklanan, Polya'nın yaklaşımı temel alındığında her bir basamağa ayrı ayrı ağırlık veren bir bilgi türüdür. Öğretmenlerin öğrencilere bu bağlamda nasıl problem çözüleceğini öğretmesi, sınıfın önünde problem çözerken ise Polya'nın işaret ettiği yaklaşımı uygulaması gerekir (Grouws, 2003).

Problemle karşılaştığımızda ilk önce problemi anlamaya çalışırız. Problemi anlamak için problemde anlatılan duruma odaklanmak, verileni ve bulunması gerekeni netleştirmek gerekir. Ne var ki öğrencilerin bir problemle karşılaştıklarındaki ilk eğilimleri anlama basamağını atlayıp hızla çözüme geçmek olmaktadır. Ders sırasında, öğrencilere problemi sunduğunuzda bir kısım öğrenci hemen işlem yapmaya başlar, aynı anda parmakları havaya kalkar, bazı öğrenciler ise bu arkadaşlarının aksine o an ne yapacaklarını şaşırmış bir şekilde, belki de problemi tam anlayamadıklarından öylece bekler, problemle uğraşmazlar. Bir diğer grup öğrenci ise problemi dikkatli okumadıkları için çeşitli hatalar yapmakta, sürekli yanlış sonuçları yüksek sesle söyleyebilmektedirler. Problem çözme etkinlikleri genellikle sınıf ortamında bu heterojen dağılımla gerçekleşir.

Her şeyden önce süreç odaklı bir problem çözme etkinliğinde öğrencilerin işlem yapmaya ve sonuca ulaşmaya odaklanmasının önüne geçmek gerekir. Polya'nın basamaklarında çözüm planının uygulanması üçüncü basamaktır ve bu sürecin öncesinde, ne kadar zaman ayrılacağı bireye göre değişse de; problemi anlama ve çözüm planı üzerine düşünme basamakları yer alır. Öğrencilerin bu basamaklara yönelik farkındalıkları geliştirilmeli ve bunlara zaman ayırmaları sağlanmalıdır.

Tüm basamaklarda öğretmen doğrudan bilgiyi sunan ve problemi çözen değil, öğrenciye rehberlik eden, öğrenciyi yönlendirmek için ona sorular yönelten konumda olmalıdır. Anlama aşamasında öğrencilerin soruyu okumasını, ne sorulduğunu anlamasını sağlamak 
önemlidir. Bu aşamada öğretmen eğer öğrencilerin zorlandığını ve probleme yönelik ilgilerini yitirdiklerini hissederse, onlara problemle ilgili sorular yöneltmeli, problemde verilen - istenen ilişkisini sorgulatmalıdır (Grouws, 2003). Çözüm planı geliştirme basamağı da benzer bir soru cevap pratiği ile öğrencilere kazandırılabilir. "Bu problemi nasıl çözersiniz?", "Bu problemi birden fazla yolla çözebilir misiniz?", "Bu problem size başka bir problemi hatırlattı mı?", "Problemin çözümünde şekil veya grafik çizmek işinize yarar mı?" şeklindeki sorular öğrencileri çözüm planına dair düşündürten sorular olacaktır. Seçilen sorular sonuca değil, sürece odaklanan sorular olmalı, öğretmen ise iyi bir dinleyici olmalıdır. Öğretmenin öğrencileri problemin çözümüne, buldukları sonuca ve problemi çözmek için sergiledikleri çabaya dair dinlemesi, öğrencilerin problem çözme ile öğrenmelerini sağlamanın temelidir (Driscoll, 2003). Problemi anlayan, çözüme nasıl ulaşacağı üzerine düşünen öğrenci çözümü uygulayıp sonuca ulaştıktan sonra da sonucun doğruluğundan emin olmak için kontrol basamağını gerçekleştirmelidir. Bu basamakta, ulaşılan sonucun problemle tutarlı olup olmadığı, işlem hatasının olup olmadığı kontrol edilir. Sadece çözüm yolu değil, tüm basamakların bütüncül bir kontrolü yapılabilir. Üçüncü aşamada elde edilen sonucun birinci adımda anlaşılan problemin gerçek cevabının olup olmadığının değerlendirilmesidir (Van de Walle, Karp ve Bay Williams, 2010). Bu nedenle belki de en önemli ama öğrenciler tarafından da en çok atlanan aşamadır.

$\mathrm{Bu}$ yaklaşım zor olmamakla birlikte geleneksel öğretim süreci içerisindeki alışkanlıklarımızın dışında bir pratik sunar. Bugün hala okullarımızda öğretmen merkezliliğin ağırlık taşıdığı rahatlıkla gözlenebilmektedir. "Öğretmen yetiştirme sürecinde güncel yaklaşım ve tartışmalara derslerimizde yer vermek, yani teorik düzlemde öğretmen adaylarını güncel eğilimlerle tanıştırmak ileriki öğretmenlik deneyimlerine ne oranda olumlu etkide bulunmaktadır?" sorusu biz eğitimcilerin hala farklı farklı başlıklarda araştırdığı bir sorudur. Bu soruya ilişkin ulaştığımız yanıtlar öğretmen yetiştirme programının niteliğinin geliştirilmesi açısından önemlidir. $\mathrm{Bu}$ araştırmada, matematik eğitiminde problem çözmeye ilişkin ağırlık kazanan yaklaşımın öğretmen yetiştirme sürecinde sınıf öğretmeni adaylarına ne oranda kazandırılabildiğine yönelik çıkarımda bulunulmaya çalışılmıştır. Öğretmen adaylarının lisans öğretimleri sürecinde aldıkları dersler ve okullarda gerçekleştirdikleri uygulamalar, lisans sürecinde edindikleri teorik ve pratik bilgi birikimini oluşturmaktadır. Öğretmen adaylarının probem çözme yeterliklerine ilişkin yapılan çıkarımlar öğretmen yetiştirme sürecine dair de veriler sunmaktadır.

$\mathrm{Bu}$ araştırmada ilk olarak sınıf öğretmeni adaylarının problem çözmeye dair pedagojik alan bilgileri önce teorik, sonra uygulama düzeyinde incelenmiştir. Daha sonra elde edilen veriler 1şı̆̆ında öğretmen yetiştirme sürecine dair çıkarımda bulunulmuştur.

\section{Araştırmanın Amacı ve Önemi}

$\mathrm{Bu}$ araştırmanın amacı sınıf öğretmeni adaylarının problem çözmeye dair pedagojik alan bilgilerini teori ve uygulama düzleminde irdeleyerek, problem çözme ve öğretmen yetiştirme sürecine ilişkin çıkarımlarda bulunmaktır.

Sınıf öğretmeni yetiştirme sürecinde, yani sınıf öğretmeni yetiştirme programında matematik ve matematik öğretimine ilişkin çok sayıda ders yer almasa da sınıf öğretmenleri matematiksel düşüncenin gelişimi ve matematiksel bilginin inşası açısından önemli bir role sahiplerdir. Matematik öğrenmenin önemli bir süreci ve aracı olarak görülmeye başlanan problem çözmenin, ilkokul sıralarından başlayarak öğretim sürecine etkili bir şekilde dâhil edilmesi gerektiği de ortadadır. Bu yargılar bir arada ele alındığında, sadece matematik öğretmenlerinin değil, sınıf öğretmenlerinin de problem çözmeye dair PAB düzeyleri önem kazanmaktadır.

Bugün gerek Türkiye'de gerekse yurt dışında öğretmen / öğretmen adaylarının problem çözme becerisi, problem çözmeye ilişkin inanç ve tutumları üzerine çok sayıda çalışmaya rastlanmaktadır (örneğin Bal ve Karacaoğlu, 2017; Guberman ve Leikin, 2013; Gümüş ve Kıllı̧, 2014; Little ve Anderson, 2015; Umay, 2017 gibi). Yalnız sınıf öğretmenlerinin ve adaylarının problem çözmeye dair PAB'nin incelenmesine yönelik yürütülen bir çalışmaya rastlanmamıştır. $\mathrm{Bu}$ çalışma ile literatürdeki bu eksiklik giderilmeye çalışılmıştır. 


\section{Yöntem}

Sınıf öğretmeni adaylarının problem çözmeye dair pedagojik alan bilgilerinin incelenmeye çalışılacağı bu araştırma, nitel araştırma yöntemlerinin kullanıldığı bir durum çalışması olarak kurgulanmıştır. Durum çalışması, araştırmacının gerçek yaşam içerisindeki güncel sınırlı bir durum hakkında gözlem, mülakat gibi çoklu bilgi kaynakları aracılığıyla detaylı ve derinlemesine bilgi topladığı bir durum betimleme çalışmasıdır (Creswell, 2013). Araştırmada odaklanılan konuyu örneklendirmek için sınırlı bir durum seçilerek, araçsal durum çalışması gerçekleştirilmiştir (Stake, 1995). Bu bağlamda, bu araştırma, Ankara'da bulunan bir devlet üniversitesinin sınıf eğitimi bölümünde öğrenim görmekte olan dördüncü sınıf öğrencilerinin Öğretmenlik Uygulaması I ve Öğretmenlik Uygulaması II dersinde gerçekleştirdikleri uygulamalar ile sınırlandırılmıştır.

\section{Çalışma Grubu}

Araştırma, Ankara'da bulunan bir devlet üniversitesinin sınıf eğitimi bölümü 4. sınıfta öğrenim görmekte olan, 17 sınıf öğretmeni adayı ile gerçekleştirilmiştir. Bu öğrencilerin 13'ü kadın, 4'ü erkektir ve bu dağılım 4. sınıftaki öğretmen adaylarının cinsiyete göre dağılımı ile uyumludur. 4. sınıfa devam eden sınıf öğretmeni adaylarının seçilmesindeki etken bu sınıf düzeyindeki ögretmen adaylarının matematik ve matematik öğretimine ilişkin tüm dersleri almış olmalarıdır. 1. sınıftaki Temel Matematik I ve II ve 3. sınıftaki Matematik Öğretimi I ve II dersleri problem çözme ve problem çözme ile öğretime ilişkin temel bilgileri içermektedir. Ayrıca, 17 kişi genel akademik ortalamaları dikkate alınarak, akademik ortalamaları açısından bir heterojenliği taşıyacak şekilde seçilmiştir. Tüm bu nedenlerle amaçsal bir örneklem oluşturulmuştur. Amaçsal örneklem araştırmacıya küçük bir örneklem alınarak, evrenin farklı karakteristik özelliklerini içinde barındırabilme olanağı sunmaktadır (Black, 2002).

\section{Veri Toplama Süreci ve Araçları}

Bir durum çalışması olarak gerçekleştirilen bu araştırmada veri toplama araçları olarak sınıf öğretmeni adaylarının Öğretmenlik Uygulaması I dersinde doldurdukları, kendi öğretmen gözlemlerini içeren yapılandırılmamış gözlem formu, Öğretmenlik Uygulaması II dersinde gerçekleştirdikleri ders anlatımına ilişkin araştırmacının gözlemi ve sınıf öğretmeni adaylarıyla gerçekleştirilen yarı yapılandırılmış görüşme kullanılmıştır.

Veri toplama süreci, 2015-2016 eğitim-öğretim y1lının güz döneminde başlamış, güz döneminde Öğretmenlik Uygulaması I dersini alan sınıf öğretmeni adaylarından derslerine girdikleri öğretmenin sınıf içerisindeki problem çözme davranışlarını gözlemlemeleri istenmiştir. Öğretmen adaylarına yapılandırılmış bir gözlem formu verilmemiştir. Onlardan gözlem yaptıkları sınıftaki öğretmenin problem çözme sürecindeki davranışlarını, önceki derslerinde edindikleri bilgiler doğrultusunda gözlemleyip, bir değerlendirme raporu yazmaları istenmiştir. Dönem sonunda kendilerinden istenen gözlem raporu toplanmıştır. Bu gözlem raporu ile amaçlanan öğretmen adaylarının sahip oldukları teorik bilgilere, hazırladıkları raporlar ile ulaşmaktır.

2015-2016 eğitim-öğretim yılının bahar döneminde ise öğretmen adaylarından problem çözme ile öğretim yaklaşımına uygun bir ders planı hazırlamaları ve bu planı uygulamaları istenmiştir. 17 sınıf öğretmeni adayının 1'er ders saati süren uygulamaları araştırmacı tarafından takip edilmiş ve gerekli izinler alınarak video kaydına alınmıştır. Öğretmen adaylarının ders anlatım uygulamaları sahip oldukları pedagojik alan bilgisinin pratik düzlemde ortaya konulması amacı ile kurgulanmıştır.

Araştırmada son olarak 17 öğretmen adayı ile yarı yapılandırılmış görüşme gerçekleştirilmiştir. Öğretmen adaylarının gerçekleştirdikleri gözlem ve ders anlatım uygulamaları doğrultusunda elde edilen veriler 1şı̆̆ında detaylandırılan bir görüşme gerçekleştirilmiştir. Görüşme formunda, "Öğretmenin problem çözme davranışını gözlemlerken hangi parametrelere dikkat etmiştiniz? Bu parametreleri nasıl geliştirdiniz?", "Sizden problem çözmeye dayalı bir ders planlamanız istenmişti, planı hazırlarken nelere dikkat ettiniz?", "Ders anlatımınız sırasında zorlandınız mı? Hangi noktalarda?", "Bir önceki dönem öğretmeni 
gözlemlerken kullandığınız parametrelere ders anlatırken de dikkat ettiniz mi? Etmediyseniz / edemediyseniz bunun gerekçesi nedir sizce?", "Kendinizi bu uygulamaların ardından problem çözmeye dayalı bir ders işleme bakımından yeterli hissediyor musunuz? Niçin?" vb ana sorular bulunmaktadır. Bu görüşmeler öğretmen adaylarının izni ile kaydedilmiş, yaklaşık $30 \mathrm{dk}$ sürmüş ve ardından çözümlenmiştir.

\section{Verilerin Analizi}

Verilerin analizinde içerik analizi yöntemi kullanılmıştır. İçerik analizinde birbirine benzeyen veriler, belirli kavram ve temalar 1şığında bir araya getirilir ve okuyucunun anlayabileceği bir şekilde düzenlenerek yorumlanır (Yıldırım ve Şimşek, 2006).

$\mathrm{Bu}$ araştırmada, sınıf öğretmeni adaylarından toplanan gözlem formları ve ders uygulamalarına yönelik videolardan elde edilen veriler Polya'nın problem çözme basamakları temel alınarak incelenmiştir. Öğretmen adaylarının kendi gözlemlerine ilişkin hazırladıkları raporda bu basamaklara ne oranda ve hangi bağlamda yer verildiği analiz edilmiştir. Ders anlatımlarında da benzer bir yol izlenmiştir. Problemi anlamak, çözüm planı geliştirmek, planı uygulamak ve kontrol ana temaları altında toplanan veriler daha sonra ilgili literatüre sadık kalınarak kodlanmıştır. Kodlama güvenirliği için araştırmacıya ek olarak, "problem çözme" literatürüne hâkim başka bir akademisyen tarafindan da veriler kodlanmış ve daha sonra kodlamalar karşılaştırılmıştır. Yapılan kodlamalarda farklılığa rastlanmamıştır.

Analizler raporlaştırılırken, çalışma grubundaki katılımcıların cinsiyetlerine sadık kalınarak, her birine yeni bir isim verilmiştir. Makalede gerçek isimleri değil, sonradan verilen bu isimler kullanılmıştır.

\section{Bulgular}

Bulgular Polya'nın problem çözme aşamalarını temel alan temalar altında ele alınacaktır. Öğretmen adayların problem çözmeye dair pedagojik alan bilgileri, teorik bilgi ve uygulama boyutunda, bu temalar altında karşılaştırılarak sunulacaktır. Son olarak da öğretmen adayları ile gerçekleştirilen görüşmelerden elde edilen veriler, öğretmen yetiştirme programının yeterlikleri bağlamında tartışılacaktır.

\section{Anlama Aşaması}

$\mathrm{Bu}$ aşamada öğrencilerin problemin ne ile ilgili olduğunu anlamaları, neyin sorulduğunu kavramaları sağlanmalıdır. Sınıf düzeyine göre öğretmenin bu aşamadaki etkinliği değişebilecektir. Okuma-yazma becerisi henüz gelişmekte olan 1. sınıf öğrencilerinin bir problemi anlaması ile 4. sınıf öğrencilerinin problemi anlamasını sağlamak arasında farklılıklar vardır, bu süreçlerde farklı stratejiler kullanılmalıdır.

İlk olarak, sınıf öğretmeni adaylarının gerçekleştirdikleri ders gözlemlerine dayalı bulgular incelenmiştir. On iki sınıf öğretmeni adayı, gözlemlerine dair hazırladıkları raporda ögretmenlerin ya bu aşamayı es geçmesini eleştirerek ya da problemin anlaşılması için sınıfta yaptıklarını olumlayarak "anlama" aşamasının problem çözme sürecindeki yerine değinmişlerdir. Öğretmen adaylarının uygulamaları incelendiğinde ise sadece 6 öğretmen adayının dersinde problem çözülürken bu aşamaya yer verdiği gözlenmiştir. Bu 6 öğretmen adayı raporunda bu aşamaya değinenlerdir. Raporunda değindiği halde uygulamada bu aşamaya yer vermeyen 6 öğretmen adayının varlığı dikkat çekicidir. Diğer 5 öğretmen adayı ise anlama aşamasına ne raporunda, ne de uygulama aşamasında yer vermemiştir. Anlama aşamasına ilişkin elde edilen bulgular Tablo 1'de verilmiştir.

Tablo 1

Anlama Aşamasına İlişkin Bulgular

\begin{tabular}{ccccc}
\hline \multirow{2}{*}{ Anlama Aşaması } & \multicolumn{2}{c}{ Gözlem Raporunda } & \multicolumn{2}{c}{ Uygulamada } \\
& Yer verdi & Yer vermedi & Uyguladı & Uygulamadı \\
\cline { 2 - 5 } & 12 & 5 & 6 & 11 \\
\hline
\end{tabular}


Uygulamada anlama aşamasına yer vermeyen 11 öğretmen adayının hepsi öğrencilere problemi sunduktan sonra onları problemi çözmeleri için doğrudan yönlendirmişlerdir. Bunlardan sadece 4'ü problem çözülememiş veya problemin çözümü sınıfın geneli tarafından anlaşılmamış ise öğrencileri problemi "iyi okumadıkları için anlamadıkları" konusunda uyarmıştır. Bu öğretmen adaylarından birisi olan Sinan, öğrenciler yerlerinde problemi çözmeye çalışrken zorlananlara "İki kare vermiş, onları çiz mesela, kenar uzunluğu neydi birisinin? Onu yaz bir düşün bakalım" veya "İki kare vermiş ya önce bir çiz, bir de kenar uzunluğu vermiş ya o karenin, işte çevresini bul" şeklinde doğrudan yönlendirmelerde bulunmayı tercih etmiş, problemi çözemeyen sayısı artınca da tahtaya geçip "Soruyu tam olarak okumuyorsunuz, ondan dolayı da anlamıyorsunuz, ne vermişti, ne istedi? Ne istendiğini şekil olarak gösterirseniz belki daha iyi anlayacaksınız." yönlendirmesinde bulunmuştur. Bu öğretmen adaylarının daha sonraki sorularda da aynı eğilimi devam ettikleri gözlenmiştir. Schroeder ve Lester'a (1989) göre öğretmenlerin doğrudan kendi fikirlerini sunmasına dayanan bu yaklaşım, öğrencileri kendi mevcut bilgileri ile problemi çözmek için fikir geliştiren bağımsız düşünürler olmaktan alıkoyar ve öğrencileri pasif öğrenen durumuna koyar.

Öğrencilerin soruyu çözmeye geçmesini engelleyen ve soruda ne verildiği üzerine tartışma yürüterek anlama aşamasına yer veren öğretmen adaylarının izledikleri stratejilerin de sınıf düzeyine göre farklılaştığı gözlenmiştir. Birinci sınıfların dersine giren 2 öğretmen adayı (yapılan görüşmede öğrencilerin okuma ve yazma becerilerinin henüz tam gelişmemiş olmasından kaynaklı bu stratejileri tercih ettiklerini belirtmişlerdir) problemi yazılı olarak öğrencilere sunmuş ve ayrıca birkaç kez onlardan problemi yüksek sesle okumalarını da istemişlerdir. Bazı durumlarda öğrencilerden probleme ilişkin canlandırma yapmalarını veya bir öğrenciyi seçerek ondan problemde anlatılanları yeniden, aklında kaldığınca masal gibi anlatmasını da istemişlerdir. Klasik "verilen ne? İstenen ne?" sorgulamasının dışına çıkan bu yaklaşımın problemin anlaşılmasında etkili olduğu gözlenmiştir. Diğer öğretmen adaylarının da benzer bir yaklaşımla problemi çözmeye istekli olan ve hemen parmak kaldıran öğrencileri "problemi şimdi çözmüyoruz, önce problemi anlayalım" şeklindeki yönlendirmelerle durdurup, her problemde öğrencilerle ilk önce problemde anlatılanlar üzerine tartışma yürüttüğü gözlenmiştir.

\section{Strateji Geliştirme Aşaması}

$\mathrm{Bu}$ aşama problem çözme süreci içerisinde hangi yöntemi ve işlemi niçin kullandığımızın farkındalığını sağlayan ve bu nedenle problem çözme becerisi geliştirilirken vurgulanması gereken bir aşamadır. Problemin nasıl çözüleceğine, hangi stratejilerin kullanılacağına dair bir akıl yürütme gerektirir. İşlem yapmaya başlamadan önce strateji ve işlemler üzerine düşünme alışkanlığının geliştirilmesidir. İlkokulda yoğun olarak dört işlem bilgisi kullanılırken bu süreç dört işlemin veya ele alınan sayı gruplarının (doğal sayı, kesir gibi) kavramsal bilgilerini tekrar etmeyi de içerir.

Öğretmen adaylarının gözlemlerine dair hazırladıkları rapor incelendiğinde 12 öğretmen adayının raporunda "strateji geliştirme" aşamasına değindiği, 5 adayın değinmediği görülmektedir. Yalnız, bu 12 öğretmen adayının 7 tanesinin strateji geliştirme aşamasını zihinlerinde yanlış kodladığı görülmektedir. Bu 7 öğretmen adayı öğretmenin problemi verdikten sonra, sınıfa problemi çözmesi için tanıdığı zamanı strateji geliştirme aşaması olarak tanımlamışlardır. Hâlbuki bu süreçte öğretmenden beklenen öğrencilerin problemi nasıl çözeceklerine dair düşünmelerini sağlamaktır. Bu aşamaya öğrencilere problemi çözebilmek için hangi yöntemlerin kullanılabileceği sorularak başlanabilir. Örneğin diğer 5 öğretmen aday öğretmenlerin çözüme geçilmeden önce çözüme yönelik sordukları sorular üzerinden bu aşamaya doğru olarak değinmişlerdir. Son durumda 5 öğretmen adayı raporunda bu aşamaya hiç değinmezken, 5 öğretmen adayı bu aşamaya doğru bir içerikle değinmiş, 7 öğretmen adayı ise bu aşamanın farkında olup, içeriğini yanlış kavramıştır.

Öğretmen adaylarının uygulamasına bakıldığında ise, raporunda strateji geliştirme aşamasına doğru bir şekilde değinmiş olan 2 öğretmen adayının sadece bu aşamayı uyguladığ görülmektedir. Teorik düzlemde ortaya konan bilgiye karşılık, uygulama boyutunda bu bilginin 
kullanılmasında ciddi bir düşüş gözlenmektedir. Strateji geliştirme aşamasına ilişkin bulgular Tablo 2'de verilmiştir.

Tablo 2

Strateji Geliştirme Aşamasına İlişkin Bulgular

\begin{tabular}{|c|c|c|c|c|c|}
\hline \multirow{5}{*}{$\begin{array}{l}\text { Strateji } \\
\text { Geliştirme } \\
\text { Aşaması }\end{array}$} & \multicolumn{3}{|c|}{ Gözlem Raporunda } & \multicolumn{2}{|c|}{ Uygulamada } \\
\hline & Yer verdi & & Yer vermedi & Uygulad1 & Uygulamad1 \\
\hline & Doğru & Yanlış & & & \\
\hline & İçerik & İçerik & & & \\
\hline & 5 & 7 & 5 & 2 & 15 \\
\hline
\end{tabular}

Uygulama dersinde bu aşamaya yer vermeyen öğretmen adaylarındaki (15 kişi) genel eğilim, problemi öğrencilere sunduktan sonra onların hemen yerlerinde problemi çözmelerini istemeleri olmuştur. 11 kişi bu eğilimi taşırken, 4 öğretmen adayı ise sınıfın problemin çözümüne dair düşünmesine firsat vermeden öğrencilerden birisini seçip tahtaya kaldırmayı tercih etmiştir. 2. sınıfların dersine giren Mehmet derste tam, çeyrek, yarım kavramlarını ele almıştır. Öğrencilere farklı renklerde daireler dağıtan Mehmet, onlardan bu daireleri iki yarım parçaya ayırmalarını istemiștir. Strateji geliștirme aşamasını uygulamayan Mehmet, doğrudan öğrencileri yerlerinde soruda isteneni uygulamaya yönlendirmiştir. Uygulamanın sonunda öğrencilerin çoğunun "yarım" ve "iki eşit parça" ilişkisine dikkat etmeden makasla ellerindeki daireleri farklı büyüklükteki parçalara böldüğü gözlenmiştir.

Buna karşın uygulama dersinde bu aşamaya yer veren 2 öğretmen adayından biri olan İpek 4. sınıflara girdiği dersinde, problemin anlaşılması için sınıfça yürütülen tartışmanın hemen ardından soruyu tahtada çözmek isteyen bir öğrenci ile aşağıdaki diyaloğu yaşamıştır.

Öğrenci: [öğrenci parmak kaldırmakta] Öğretmenim çözeyim mi? Ipek: Indirelim parmaklarl, ne istiyor soruda bizden? Önce ona bakalım, soruda sorulanı kaçırmayalım.

Öğrenci: Okulun mevcudu isteniyor.

Ipek: Tamam, okulun mevcudunu bulmak için ne yapmallyız? Bana soruyu nasıl çözmeyi düşündüğ̈̈nü anlatır misin?

Ögrenci: Ö̆rretmenim, önce kı öğrenci sayısını bulucam. Sonra onunla erkek ögrenci sayısın topliycam, öyle değil mi?

İpek bu diyalogda görüldüğü üzere problem çözme eğilimdeki öğrenciye müdehale ederek onu problemi çözmekten uzaklaştırmış ve çözüm stratejisi üzerine düşünmesini sağlamıştır.

\section{Çözümü Uygulama Aşaması}

$\mathrm{Bu}$ aşamada öğrenciler düşündükleri stratejileri uygulamaya geçirir, çözümü gerçekleştirmeye çalışır. Ayrıca sınıf içerisinde gerçekleştirilen tartışmalar da önemlidir. Tüm sınıfın çözüm aşamasına dâhil edilmesi, öğrencilerin önceki aşamalarda yaşadığı boşlukların fark edilmesi ve giderilmesi bu aşamada mümkün kılınabilir. Öğretmen daha çok gözlemci ve rehber niteliğinde olmalıdır. Problemi anlayan ve nasıl çözeceği üzerine düşünen öğrenci çözüm aşamasına rahatlıkla geçebilir. Problemi çözmekte zorlanan öğrenci için problemi anlamamış oluşu, kullandığı çözüm stratejisinde zorlanıyor oluşu gibi bir dizi gerekçe geçerli olabilir. Öğretmenin bu aşamada öğrencileri gözlemlemesi, hataların veya problemi çözemeyişlerin nedenlerini anlamaya çalışması, zorlandıkları noktada öğrencileri doğrudan yönlendirmesi değil de kurulan diyalogda dinleyici olması önemlidir. Çözümün gerçekleştirilememesinin gerekçesi fark edilip bu noktadaki eksiklikler gerek öğrenci ile tartışılarak, gerekse sınıf içi tartı̧̧ma yaratılarak giderilmeye çalışılabilir. Problem çözme ile öğretim yaklaşımında, yani süreç odaklı bir problem çözme yaklaşımında sadece doğru sonuca ulaşmaya odaklanmayan bu yaklaşım önemlidir. 
Peki, problem çözme için öğretim yaklaşımında nasıl olmaktadır? Sınıf içi tartışmanın az olduğu, doğru sonuca ulaşmak adına genellikle problemi çözen veya çözmeye istekli öğrencilerin hızla tahtaya kaldırıldığı, öğretmenin problemin çözümüne dair öğrencileri doğrudan yönlendirdiği bir çözme süreci ile karşılaşılmaktadır. Çözümü uygulama aşaması uygulamada en çok zaman ayrılan ama içeriği, sahip olunan problem çözme yaklaşımına bağlı olarak değişen bir aşamadır. Çözümü uygulama aşamasına ilişkin elde edilen bulgular Tablo 3'de verilmiştir.

Tablo 3

Çözümü Uygulama Aşamasına İlişkin Bulgular

\begin{tabular}{lcccc}
\hline & \multicolumn{2}{c}{ Gözlem Raporunda } & \multicolumn{2}{c}{ Uygulamada } \\
Çözümü & Yer verdi & Yer vermedi & Uygulad1 & Uygulamad 1 \\
\cline { 2 - 5 } $\begin{array}{l}\text { Uygulama } \\
\text { Aşaması }\end{array}$ & 17 & 0 & 5 & 12 \\
\hline
\end{tabular}

Öğretmen adaylarının hazırladığı gözlem raporlarında, çözümü uygulama aşaması öğretmen adaylarının hepsi tarafından problemi öğrencilerin mi öğretmenin mi çözdüğü, öğretmenin problem çözümünde aktif rol alıp almayışı, tahtaya sadece istekli öğrencilerin kaldırılmasının eleştirilişi ve öğretmenin farklı çözüm yollarına dersinde yer verip vermeyişi bağlamları altında ele alınmıştır. Tüm öğretmen adaylarının değindiği bir aşama olmuştur ve hepsi raporlarında problem çözme ile öğretim yaklaşımı çerçevesinde bir değerlendirme sunmuştur.

Buna karşın, öğretmen adaylarının uygulamaları incelendiğinde sadece 5 öğretmen adayının bu yaklaşıma uygun bir şekilde çözümü uygulama aşamasını ele aldığı gözlenmektedir. Geri kalan 12 öğretmen adayından 2 tanesi problemleri tahtada kendisi çözerken, 2'si öğrenciler problemi çözerken sıralar arasında dolaşmak ile yetinmiş, problemin çözümünü sınıfa sunmayı tercih etmemiştir. Tüm öğretmen adayları problemi çözmeleri için az ya da çok öğrencilere zaman tanımıştır. Bu 12 öğretmen adayı bu süreci öğrenciyi dinleyip, gözlem yaparak değil, zorlandıklarını gördükleri noktada öğrencileri doğrudan çözüme yönelik yönlendirerek geçirmişlerdir.

\section{Kontrol Aşaması}

Problemi çözerek soruya verdiğimiz yanıt acaba mantıklı mı? Bir yanıtın doğruluğunu göstermek, yanıtın problem ile tutarlığının incelenmesi, soruda verilenler ile yanıt arasında mantıklı bir ilişkinin kurulmasıdır. Bu bağlamda kontrol aşaması, her ne kadar ilk etapta sadece yapılan işlemlerin kontrol edilmesini akıllara getirse de, problem çözme aşamalarının tümünün ulaşılan sonuca bağlı olarak değerlendirilmesidir. Yapılan işlemlerin kontrolü, kontrol aşamasının bir parçasıdır ama bütünü değildir.

12 ögretmen adayı hazırladıkları gözlem raporunda, öğretmenin problem çözme davranışlarını değerlendirirken kontrol aşamasına değinmiş, 5 öğretmen adayı hiç değinmemiştir. Bu 12 öğretmen adayının 10'u öğretmenin öğrencilerin defterlerine yazdıklarını kontrol ederek, 1'i öğretmenin öğrenci problemi çözdükten sonra çözümü kendisinin de anlatarak yinelediğini belirterek, bir diğeri ise öğretmenin tahtada farklı çözüm yollarını da yaptırdığını vurgulayarak kontrol aşamasına değinmişlerdir. Raporda yazılanlar bir öğretmen dışında, hiçbir öğretmenin kontrol aşamasını eksiksiz olarak ele almadığını göstermektedir, buna karşın öğretmen adaylarının betimleme ve yorumları öğretmenlerin bu davranışlarını eksikli bulmadıkları yönündedir. Örneğin Aylin raporunda "Sinıf mevcudu da uygun olduğu için, 27 kişi, ögrretmen sinıfta problem çözerken öğrencilerin defterlerini tek tek kontrol ediyor, tüm ögrencilerin işlemleri kontrol ediliyor. Bu sayede de kontrol aşamasını gerçekleştirmiş oluyor." şeklinde bir betimleme ile kontrol aşamasını işlemlerin kontrolü ile sınırlamaktadır. İpek ise gözlemlediği öğretmenin problem çözümünde sınıfi sürekli farklı çözüm yolları üzerine düşündürme eğilimini “ ... bu sayede tek bir çözüm üzerine sınırlı kalınmıyor. 'Bu soruyu başka 
nasıl çözebiliriz' sorusuna yanıt aranırken sinıfta yeniden problemde verilenler üzerine konuşuluyor, tekrar Polya'nın ikinci aşamasına dönülüyor." ş̧eklinde ifade ederek, kontrol aşamasına ilişkin daha geniş bir anlatıda bulunan tek öğretmen adayı olmuştur.

Uygulamada bu aşamayı ele alan öğretmen adayı sayısı azalmıştır. Sadece 3 öğretmen adayı dersinde farklı çözüm yollarına yer vererek, öğrencilere "Neden çözümünün doğru olduğunu düşünüyorsun?", "Peki, çözümün mantıklı mı sence? Niçin?”, "Bu bulduğun, soruda istenen mi?" şeklinde sorular yönelterek kontrol aşamasına tam olarak yer vermiştir. Bir diğer 3 öğretmen adayı ise sadece öğrencilerin yaptığı çözümü, işlemleri kontrol ederek sınırlı bir kontrol aşaması uygulamasında bulunmuştur. Geri kalan 11 sınıf öğretmeni adayı, bu aşamayı es geçerek hemen başka bir soruya geçilmesini sağlamışlardır. Kontrol aşamasına ilişkin bulgular Tablo 4'te verilmiştir.

Tablo 4

Kontrol Aşamasına İlişkin Bulgular

\begin{tabular}{|c|c|c|c|c|c|c|}
\hline \multirow[b]{3}{*}{$\begin{array}{l}\text { Kontrol } \\
\text { Aşaması }\end{array}$} & \multicolumn{3}{|c|}{ Gözlem Raporunda } & \multicolumn{3}{|c|}{ Uygulamada } \\
\hline & \multicolumn{2}{|c|}{ Yer verdi } & \multirow[t]{2}{*}{ Yer vermedi } & \multicolumn{2}{|l|}{ Uyguladi } & \multirow[t]{2}{*}{ Uygulamad1 } \\
\hline & $\begin{array}{l}\text { İçerik } \\
\text { tam }\end{array}$ & $\begin{array}{l}\text { İçerik } \\
\text { sinırlı }\end{array}$ & & $\begin{array}{l}\text { Eksiksiz } \\
\text { uygulad1 }\end{array}$ & $\begin{array}{l}\text { Sinirli } \\
\text { uyguladid }\end{array}$ & \\
\hline & 1 & 11 & 5 & 3 & 3 & 11 \\
\hline
\end{tabular}

Sınıf öğretmeni adaylarının hazırladıkları raporlarda özellikle de kontrol aşamasıyla ilgili değerlendirmelerinde ele aldıkları bir davranış da öğretmenin problem çözerken yapılan hatalara ilişkin tutumu olmuştur. 7 öğretmen adayı "hata"ya yönelik tutumu problem çözmeye ilişkin önemli bir öğretmen davranışı olarak ele almışlardır. Bu öğretmen adaylarından 4’ü bir öğrenci tahtada problem çözerken hata yaptığında öğretmenin hemen o öğrenciyi yerine oturtup, doğru yanıta ulaşan bir öğrenciyi tahtaya kaldırtmasını eleştirmiştir. 3 öğretmen adayı ise öğretmenin hataya ilişkin tutumunu olumlayarak raporunda bu kavrama yer vermiştir. $\mathrm{Bu}$ öğrencilerin ortak değerlendirmesi, hatanın öğrencilerin dikkatsizliğini, öğrenme eksiklerini veya sahip oldukları kavram yanılgılarını ortaya koyan bir durum olduğudur. Bu nedenle hata ile karşılaşıldığında hemen doğru yaklaşım sunulmamalı, hatanın üzerine gidilmeli, gerekçesi anlaşılmaya ve giderilmeye çalışılmalıdır. Bu öğretmen adayları bu bağlamda hataya yapılacak müdahaleyi problem çözme ile öğretim yaklaşımının önemli bir parçası olarak ele almışlardır. Geri kalan 10 öğretmen adayı "hata"ya ilişkin hiçbir değerlendirmede bulunmamışlardır.

Öğretmen adaylarının uygulaması incelendiğinde, bu 7 öğretmen adayının sadece 4'ünün derslerinde problem çözülürken hata yapıldığında öğrencileri ile bahsettikleri şekilde ilgilendikleri gözlenmiştir. Tüm öğretmen adayları dikkate alındığında geriye kalan 13 öğretmen adayının 2'si yapılan hatayı gözden kaçırmış, 6'sı hata yapıldığında anında müdahale edip hatayı kendisi düzeltmiş, 4'ü tahtadaki öğrencileri yerine oturtup, soruyu çözen bir öğrenciyi tahtaya kaldırmışır. 1 öğretmen adayının dersinde ise tahtada hata yapan bir öğrenci olmamıştır.

\section{Problem Çözme Davranışı ve Öğretmen Yetiştirme Süreci}

Sınıf öğretmeni adayları ile gerçekleştirilen görüşme onların gözlem ve uygulamadaki deneyimleri üzerine inşa edilmiştir. Öğretmen adaylarına ilk olarak ilk dönem gerçekleştirdikleri gözleme ilişkin sorular sorulmuştur. 17 öğretmen adayının 12'si gözlem raporunu Polya'nın problem çözme basamaklarını temel alarak oluşturmuşlardır. Bu öğretmen adayları görüşmede, bir önceki yıl aldıkları matematik öğretimi dersindeki bilgiler 1şı̆̆ında gözlemlerini gerçekleştirdiklerini belirtmişlerdir. Geri kalan 5 öğretmen adayı ise geçen yılki bilgilerini pek anımsamadıklarını, o ana kadar biriktirdikleri mesleki bilgiler ışı̆̆ında gözlem yaptıklarını söylemişlerdir. Bu kişilere Polya'nın problem çözme basamakları sorulduğunda ise doğrudan yanıt verememişler, araştırmacının hatırlatmaları ile basamaklar ve içeriklerini anımsayabilmişlerdir. Öğretmen adaylarının yaklaşı \% 29'unun aldıkları eğitim ışığında teorik 
düzlemde problem çözmeye ilişkin pedegojik alan bilgisinin gelişiminde sıkıntı olduğu görülmektedir.

Görüşmenin ikinci kısmında öğretmen adaylarına ders anlatım uygulamalarına ilişkin sorular sorulmuştur. Hazırladıkları gözlem raporları doğrultusunda 12 öğretmen adayının problem çözmeye dair pedagojik alan bilgilerinin, problem çözme ile öğretim yaklaşımı ve Polya'nın problem çözme basamaklarına ilişkin bilgi ve tartışmaları (farklı düzeylerde olsalar da) içerdiği düşünülse de gerçekleştirdikleri uygulamaya bu bilgileri yansıtmakta zorlandıkları gözlenmiştir. Bu 12 öğretmen adayının yarıya yakınının Polya'nın problem çözme aşamalarının bir kısmını uyguladığı görülmektedir. 12 öğretmen adayına, teori ve uygulama düzeyinde sergiledikleri bu farklılığın gerekçeleri de sorulmuştur. Gözlem raporunda tüm basamaklara tek tek değinen ama uygulama esnasında bu basamakları tam olarak uygulamayan öğretmen adaylarından birisi olan Ezgi ders anlatımını "uygulama başka bir şey, karşınızda gerçek ögrenciler var ve o an derste ögrendikleriniz aklınıza gelmiyor" şeklinde ele alırken, Ünal "teori başka, uygulama başka, o ikisini bir araya getirmek zor" değerlendirmesinde bulunmuştur. Görüşülen öğretmen adayları için okulda edindikleri teorik bilgiler ile öğretmenlik staj1 arasında net bir ayrım vardır ve hepsi teorik bilgilerini akılda tutarak ders anlatmanın zor olduğuna değinmişlerdir. Gerçekleştirdiği gözlem ve uygulama arasında tutarlılık bulunan Semra ise sahip olduğu teorik bilgiyi uygulamaya yansıtmanın zorluğuna şu şekilde değinmiştir; "Uygulama dersinde sürekli kendi içimden tekrarladım, önce ögrencilerin problemi anladığından emin ol, onların problemi hemen çözmelerine izin verme, tüm sinıfi tartı̧̧maya kat gibi. Ama bunu yapmak zordu benim için.".

Eğitim fakültesinde edindikleri teorik çerçeve dışında ders işleme eğilimini taşıyan öğretmen adaylarına onların uygulamasını belirleyen parametreler de sorulmuştur. Bu öğretmen adayları farklı kavramları kullansa da işledikleri dersi "kendileri nasıl öğrenmişlerse o metodu kullanma" şeklinde tanımlamışlardır. Bu doğrultudaki açıklamaların bazıları şu şekildedir:

"Sanırım ben kendim nasıl ögrendiysem öyle anlattım." (Ünal)

"Benim ögretmenlerim de hep benim yaptı̆̆ım gibi problem çözüyordu." (Evrim)

"Kendim ders anlatırken, geçen yll gördüklerimiz değil de daha eski, öğrenci olduğum zamanlar geldi aklıma. Eski ögretmenlerimin yaptıklarl geldi aklıma. Onu uyguladım” (Fulya)

Sınıf öğretmeni adayları teorik düzlemde edindikleri bilgileri içselleştiremedikleri zaman kendileri bilgiyi o yıllarda nasıl öğrenmiş iseler o şekilde öğretme eğilimi taşımışlardır.

Görüşme yapılan tüm öğretmen adayları öğretmenlik staj uygulamalarının yetersiz olduğunu, pratik yönden kendilerini yetiştiremediklerini de belirtmişlerdir. Uygulamalarındaki eksiklikleri ve zorlanmış olmalarını bu gerekçeye bağlamışlardır. Ayrıca son sınıfta KPSS'ye hazırlanma sürecinin de kendilerini olumsuz etkilediğini belirtmişlerdir. Sinan'ın aşağıda verilen açıklaması görüşme yapılan tüm öğretmen adaylarının genel eğilimini yansıtmaktadır:

"3 yıl hep teorik ders aldık, sanırım o zaman dersleri geçmek için çalışmışız sadece. Bu yıl da son sınıfa gelince hem uygulama dersimiz başladı, hem KPSS hazırlığı, hem de KPSS için dershane. Hepsini bir arada yürütmek zor. Keşke son sinıfta olmasa ögretmenlik uygulaması dersi, ben şu an okul stajımı pek düşünmüyorum açıkçası. Nasıl deyim, kendimi verdiğim bir ders değil bu. Sinava hazırlık daha önemli benim için." (Sinan)

Sonuç olarak öğretmen adayları problem çözmeye dair pedagojik alan bilgilerinin gelişiminde ortaya çıkan eksiklikleri öğretmen yetiştirme sürecine bağlamış, teorik bilgi ile pratik arasında bağ kurmakta zorlandıklarını belirtmişlerdir. Öğretmen adaylarının hemen hemen tamamı staj dersinin son sınıfta olmasını eleştirmişlerdir. 


\section{Tartışma / Sonuç ve Öneriler}

Problem çözme, bir problemin etkin bir şekilde sonuca ulaştırılması anlamının çok ötesine geçmiş, matematik öğretiminde, bilginin edinilmesinde etkin bir araç olarak kabul edilmeye başlanmıştır. Problem çözme için öğretim, problem çözme ile öğretim kavramsallaştırmaları ayrımında tanımlayabileceğimiz geleneksel ile güncel eğilimler birbirlerinden farklı problem çözme süreçleri ortaya koymaktadır. Bu yaklaşımlar bilginin edinilmesinde farklı kabulleri, farklı öğretmen ve öğrenci rollerini ve bambaşka sınıf kültürlerini ifade etmektedirler. Günümüzde öğretmen yetiştirme sürecinde problem çözme ile öğretim yaklaşımının ağırlığ artmaktadır. $\mathrm{Bu}$ makalede de bu eğilimi taşıyan bir devlet üniversitesinde okuyan sınıf öğretmeni adaylarının problem çözmeye dair pedagojik alan bilgileri teorik ve pratik düzlemde incelenmeye çalışılmıştır. Ayrıca elde edilen bulgular ile öğretmen yetiştirme süreci arasında ilişki kurulmaya da çalışılmıştır.

Polya'nın problem çözme yaklaşımı, bu alana ilişkin tek yaklaşım olmasa da en çok kabul görenidir. Bu araştırmada sınıf öğretmeni adaylarından sahip olmaları beklenen problem çözmeye dair pedagojik alan bilgisi bu aşamalar temel alınarak incelenmiştir. Araştırmaya katılan 17 öğretmen adayından 5'inin gerek gözlem formunda gerekse uygulamalarında bu aşamaları dikkate almadığı görülmektedir. Öğretmen adaylarının \% 29'unda problem çözmeye dair güncel bir pedagojik alan bilgisinin varlığı gözlenememiştir, bu öğretmen adayları geleneksel bir yaklaşımla, problem çözme için öğretim anlayışına sahip olarak, öğretim deneyimlerini şekillendirmişlerdir. Geri kalan 12 öğretmen adayının sahip olduğu bilgi düzeyinde ise teorik ve pratik açıdan ciddi farklılıklar gözlenmiş̧tir.

Anlama aşamasını uygulama esnasında sadece 6 öğretmen adayı etkin bir şekilde uygulamıştır. Tüm katılımcılar dikkate alındığında anlama aşamasının uygulanma oranı \% 35 iken, sadece gözlem formunda bu aşamayı ele alan öğretmen adayları dikkate alındığında oran $\% 50$ 'dir. Teorik düzeyde bu bilgiye sahip öğretmen adaylarının ancak yarısı bu bilgiyi uygulamaya geçirebilmiştir.

Strateji geliştirme aşamasında ise bu aşamaya gözlem formunda değinen öğretmen adaylarının 7'sinin yanlış bir içerikle bu aşamayı ele aldığı görülmüştür. Polya'nın ikinci aşaması bu öğretmen adayları için problemi çözmeleri için öğrencilere zaman tanımak anlamını taşımaktadır. $\mathrm{Bu}$ nedenle bu öğretmen adayları "strateji geliştirme aşaması" kavramını kullanmış olsalar da sadece 5 öğretmen adayının bu aşamayı doğru bir içerikle, problemin nasıl çözüleceği ve çözüm yöntemleri üzerine akıl yürütme ve tartışmayı içeren bir aşama olarak ele aldığı söylenebilir. $\mathrm{Bu}$ aşamayı uygulayan kişi sayısı ise sadece 2'dir. Tüm öğretmen adaylarının sadece \% 12 si bu aşamayı uygulamıştır. En düşük oranda uygulanan aşama bu olmuştur.

Tüm öğretmen adaylarının gözlem raporunda değindiği aşama çözümü uygulama aşaması olmuştur. Tüm öğretmen adayları bu aşamaya ilişkin gözlemlerini öğrenci merkezli bir yaklaşımla ele alırken, etkin bir şekilde bu aşamayı uygulayan sadece 5 kişi olmuştur. Bu aşamanın uygulanma oranı \% 29'dur.

Son aşama olan kontrol aşamasına raporda değinen 12 öğretmen adayı olmuştur. $\mathrm{Bu}$ adayların 11'i kontrolü yapılan işlemlerin sağlaması olarak, eksikli bir içerikte ele alırken sadece tek bir öğretmen adayı bu aşamayı bir bütün olarak ele almıştır. Uygulama boyutuna bakıldığında ise 6 öğretmen adayının eksiksiz bir içerikte bu aşamayı ele aldığı görülmektedir. Tüm öğretmen adayları dikkate alındığında bu aşamanın uygulanma oranı \% 35'de kalmıştır.

Tüm aşamalar bir arada dikkate alındığında, öğretmen adaylarının Polya'nın problem çözme aşamalarına yönelik farkındalığı \% 71'de kalmıştır. Bu öğretmen adaylarının sahip oldukları kuramsal bilgiyi uygulama aşamasına geçirmelerinde ise oran yarıya düşmektedir. Her bir aşamada uygulama düzeyleri \% 12 ile 35 arasında değişmektedir. Öğretmen adaylarının problem çözmeye dayalı pedagojik alan bilgilerini bu bağlamda değerlendirirsek; öğretmen adaylarının \% 71'i problem çözme ile ögretim temelinde bir teorik bilgi ortaya koyarken, bu bilginin uygulama boyutuna yansımasında oran daha da düşmektedir.

Pedagojik alan bilgisinin teori ve pratik düzlemde ortaya konmasında ortaya çıkan bu fark dikkat çekicidir. Bu fark başka araştırmalarla da irdelenebilir ve farkı yaratan gerekçelerin 
ele alınması yeni çalışmaların konusu olabilir. $\mathrm{Bu}$ araştırmada ortaya çıkan bu farka dair öğretmen adaylarının görüşlerine de başvurulmuştur. Öğretmen adayları araştırmanın sonunda gerçekleştirilen görüşmede ortaya çıan bu farkı öğretmen yetiştirme süreciyle ilişkilendirmişlerdir. Teorik bilgiye sahip olsalar da bunu pratik uygulamaya aktarmakta zorlandıklarını belirten öğretmen adayları, öğretmen yetiştirme sürecini pratik becerileri geliştirmediği için eleştirmiş, son sınıfta aldıkları Öğretmenlik Uygulaması derslerinin zamanlamasının yanlış olduğunu belirtmişlerdir.

Öğretmenlik stajı öğretmen yetiştirme sürecinin önemli bir parçasıdır. Bugün öğretmen yetiştirme programları dünya ölçeğinde incelendiğinde, her bir ülkede staj uygulamasının farklı bağlam ve yoğunluklarda bu programlarda yer aldığ görülmektedir. Türkiye'de her öğretmen aday1 6. yarıyıldan itibaren 3 yarıyıllık süre kapsamında, Okul Deneyimi ve Öğretmenlik Uygulaması dersleri kapsamında haftada bir gün okul stajına gitmektedir. Hollanda'da ilk ve ortaöğretim düzeyinde öğretmen yetiştiren kurumlarda ise bu süreç 1. sınıftan itibaren başlar ve her y1l ders kredisinin ortalama \%25'i uygulama derslerine ayrilmaktadır, Romanya'da da uygulama dersi birinci sınıftan itibaren başlamaktadır (Ergun ve Ersoy, 2016). Finlandiya' da da uygulama dersleri 1. dönemden itibaren başlayarak lisans öğretimi sürecine yayılmaktadır (Aykaç, Kabaran ve Bilgin, 2014). Eğitim sisteminde merkeziyetçi bir yapıya sahip olmayan, bu temelde eyaletlere göre farklılıklar taşıyan ABD'de, Virginia Üniversitesinde ise öğretmen adayları 2. sınıftan itibaren her yıl uygulama dersleri almaktadır (Külekçi ve Bulut, 2010). Almanya ve Fransa'da ise öğretmen yetiştirme süreçlerinde, öğretmen adaylarının aktif olarak öğretmenlik uygulaması yaptıkları süreç Türkiye'ye göre daha fazladır (Uygun, Ergen ve Öztürk, 2011). Türkiye'de Öğretmenlik Uygulaması ve Okul Deneyimi gibi derslerin var olmasına karşın öğretmen yetiştirme sürecinde uygulama boyutunun etkili bir şekilde hayata geçirilmediği ve yetersiz olduğu düşünülmektedir (Paker, 2008; Uygun ve diğerleri, 2011). Türkiye'nin öğretmen yetiştirme süreci ile diğer ülkelerin öğretmen yetiştirme programları karşılaştırıldığında da bu yetersizlik ortaya çıkmaktadır. Öğretmen adaylarının bu araştırmada ortaya çıkan problem çözmeye dair pedagojik alan bilgilerindeki eksikliklerde, yani teorik bilgi ve pratik uygulama arasındaki farklılıkta bu yetersizliğin etkili olduğu düşünülmektedir.

Öğretmen yetiştirme programlarının gözden geçirilerek, uygulama derslerinin sayısının artırılması, daha erken dönemlerde başlatılması ve teorik içerikli dersler ile uygulama arasında daha etkin bir ilişkinin kurulması gerekmektedir.

\section{Kaynaklar}

Aykaç, N., Kabaran, H. ve Bilgin, H. (2014). Türkiye'de ve bazı Avrupa Birliği ülkelerindeki öğretmen yetiştirme uygulamalarının karşılaştırılmalı olarak incelenmesi (Almanya, Finlandiya, Fransa, İngiltere ve Türkiye örneği). Turkish Studies - International Periodical For The Languages, Literature and History of Turkish or Turkic, 9(3), 279292.

Bal, A.P. ve Karacaoğlu, A. (2017). Cebirsel sözel problemleri çözme stratejileri ve hatalarının analizi: Öğretmen boyutu. International Journal of Social Sciences and Education Research, 3(2), 448-455.

Ball, D. L. (1990). The mathematical understandings that prospective teachers bring to teacher education. Elementary School Journal, 90, 449-466.

Black, T. R. (2002). Understanding social science research (2nd Edition), London: Sage Pub.

Bodner, G. M. (1987). The role of algorithms in teaching problem solving. Journal of Chemical Education, 64(6), 513-514.

Creswell, J. W. (2013). Nitel araştirma yöntemleri beş yaklaşima göre nitel araştirma ve araştirma deseni, M. Bütün ve S. B. Demir (Çev.), Ankara: Siyasal Kitapevi.

Çakan, M. (2004). Öğretmenlerin ölçme-değerlendirme uygulamalari ve yeterlik düzeyleri: İlk ve ortaöğretim. Ankara Üniversitesi Eğitim Bilimleri Fakültesi Dergisi, 37(2), 99-114.

Demir, S. ve Bozkurt, A. (2011). İlköğretim matematik öğretmenlerinin teknoloji entegrasyonundaki öğretmen yeterliklerine ilişkin görüşleri. İlköğretim Online, 10(3), 850-860. 
Driscoll, M. (2003). The sound of problem solving. H. L. Schoen and R. Charles (Yay. Haz.), Teaching Mathematics Through Problem Solving : Grades 6-12 içinde (s. 161-176). Reston, VA: National Council of Teachers of Mathematics.

Ergun, M. ve Ersoy, Ö. (2014). Hollanda, Romanya ve Türkiye'deki sınıf öğretmeni yetiştirme sistemlerinin karşılaştırılması. Kastamonu Eğitim Dergisi, 22(2), 673-700.

Grouws, D. A. (2003). The teacher's role in teaching mathematics through problem solving. In H. L. Schoen ve R. Charles (Yay. Haz.), Teaching Mathematics Through Problem Solving: Grades 6-12 içinde (ss. 129-142). Reston, VA: National Council of Teachers of Mathematics.

Guberman, R. ve Leikin, R. J (2013). Interesting and difficult mathematical problems: Changing teachers' views by employing multiple-solution tasks. Journal of Mathematics Teacher Education, 16(33). https://doi.org/10.1007/s10857-012-9210-7

Gümüş, F. Ö. ve Umay, A. (2017). Problem çözme stratejileri öğretiminin ilköğretim matematik öğretmen adaylarının kavramsal/işlemsel çözüm tercihlerine ve problem çözme performansına etkisi. Illkögretim Online, 16(2), 746-764.

Hill, H. C., Rowan, B. ve Ball, D. L. (2005). Effects of teachers' mathematical knowledge for teaching on student achievement. American Educational Research Journal, 42(2), 371406.

Kılıç, Ç. (2014). Sınıf öğretmenlerinin problem kurmayı algılayış biçimlerinin belirlenmesi. Kastamonu Eğitim Dergisi, 22(1), 203-214.

Külekçi E. ve Bulut, L. (2010). Türkiye ve ABD'deki öğretmen yetiştirme sistemlerinin karşılaştırılması. International Conference on New Trends in Education and Their Implications. Antalya, 11-13 Kasim 2010, 210-215.

Little, J. ve Anderson, J. (2015). What factors support or inhibit secondary mathematics preservice teachers' implementation of problem-solving tasks during professional experience? Asia-Pacific Journal of Teacher Education, 44(5), 504-521.

MEB - T.C. Milli Ĕgitim Bakanlı̆̆ı (2015). İlkokul Matematik Dersi Öğretim Programı. Ankara: Milli Eğitim Basımevi.

National Council of Teachers of Mathematics (NCTM) (2000). Principles and standards for school mathematics. Reston, VA: NCTM.

Paker, T. (2008). Öğretmenlik uygulamasında öğretmen adaylarının uygulama öğretmeni ve öğretim elemanının yönlendirmesiyle ilgili karşılaştıkları sorunlar. Pamukkale Ünivrsitesi Eğitim Fakültesi Dergisi, 1(23), 132-139.

Polya, G. (1973). How to solve it: A new aspect of mathematical method. Princeton, N.J.: Princeton Uni. Press.

Saeli, M. J., Perrent, W. ve Jochens Zwaneveld, B. (2011). Teaching programming in secondary school: A pedagogical content knowledge perspective. Informatics in Education, 10(1), 73-88.

Schroeder, T. L. ve Lester, F. K. (1989). Developing understanding in mathematics via problem solving. P. R. Trafton ve A. P. Shulte (Yay. haz.). New Directions For Elementary School Mathematics içinde (s. 31-42). Reston, VA: National Council of Teachers of Mathematics.

Shulman, L. S. (1987). Knowledge and teaching: Foundation of the new reform. Harvard Educational Review, 57(1), 1-22.

Stake, R. (1995). The art of case study research. Thousand Oaks, CA: Sage.

Stice, J. E. (2007). Teaching problem solving, Erişim adresi: https://inst.eecs.berkeley.edu/ $\sim$ ee301/fa13/Readings/teaching_problem_solving_stice.pdf

Torp, L. ve Sage, S. (2002). Problems as possibilities: Problem-based learning for K-16 education. Alexandria. VA : ASCD.

Uygun, S., Ergen, G. ve Öztürk, İ. H. (2011). Türkiye, Almanya ve Fransa'da öğretmen eğitimi programlarında uygulama eğitiminin karşılaştırılması. Ilköğretim Online, 10(2), 389405 . 
Van de Walle, J. A., Karp, K. S. ve Bay Williams, J. M. (2010). Elementary and middle school mathematics: Teaching developmentally. (7 ed.) New York, NY: Pearson Education.

Yıldırım, A. ve Şimşek, H. (2006). Sosyal bilimlerde nitel araştırma yöntemleri. Ankara: Seçkin Yayıncilik.

\section{Extended Abstract}

\section{Introduction}

Problem solving is one of the main topic whose importance has been increased in mathematics education recently. As in many educational reforms in the world, more attention has also been given to problem solving in new curriculum changes in Turkey. Problem solving is not only a target of learning mathematics, but also it is a basic learning tool of learning mathematics. All students from the pre-school through the high school to be able to;

- build new knowledge by the help of problem solving;

- solve problems that appear in mathematics and other contexts;

- apply and adapt a wide range of appropriate strategies to solve the problem;

- follow up the problem-solving process (NCTM, 2000).

This approach has increased the importance of teaching through problem solving. With this current approach, problem solving goes far beyond being a question-solving activity that is dealt with immediately after finishing the topic. Problem solving is now considered as an important component of the learning process. This approach requires a different classroom activity than traditional, teacher-centered methods. The role of the teacher in this teaching process is important for the development of student problem-solving skills.

Today, there are many studies on problem solving in the literature. An important part of these studies is based on Polya's (1973) four problem solving steps; understaning the problem, devising a plan, carrying out the plan and looking back. If we assign a central role to problem solving in the teaching process, it is important for teachers to have teaching through problem solving knowledge and Polya's problem solving steps knowledge together and also to have the ability to combine these two.

\section{Method}

The aim of this research is to examine prospective teachers' pedagogical content knowledge in the context of problem solving in theory and practice. This research was designed as a case study using qualitative research methods and it was conducted with 17 prospective primary teachers who were students at a state university in Ankara. 13 of these students were female and 4 of them were male. Unstructured observation form that prospective teachers filled in Practice Teaching I course, researcher's observations towards prospective teacher's lectures at Practice Teaching II course and also semi-structured interviews with prospective teachers were used as data collection tools in this research. Content analysis method was used in the analysis of the data and it was based on Polya's problem solving steps.

\section{Results and Discussion}

Findings are presented under the themes that are the Polya's problem solving steps. In other words, prospective teachers' pedagogical content knowledge in the context of problem solving in theory and practice is discussed under these themes. And finally, the data obtained from the interviews with the prospective teachers are discussed in the context of the competencies of the teacher training program in Turkey.

When the findings are examined, it's seen that 5 out of the 17 prospective teachers did not take into consideration the Polya's problem solving steps. These prospective teachers shaped their teaching experience with a traditional approach, they used teaching for problem solving approach. The other 12 prospective teachers had teaching through problem solving knowledge 
and Polya's problem solving steps knowledge together sometimes in an incorrect, sometimes in an incomplete and sometimes in a complete content. The rates of mentioning Polya's steps at their reports are approximately as follows: understaning the problem $71 \%$, devising a plan $71 \%$, carrying out the plan $100 \%$ and looking back $71 \%$. But it's also seen that there is a serious difference between the theoretical knowledge and their teaching practice of the remaining 12 prospective teachers on problem solving. The rate of applying theory to practice decreased by half. The rates of implementing Polya's steps at their teaching practice are approximately as follows: understaning the problem $35 \%$, devising a plan $12 \%$, carrying out the plan $29 \%$ and looking back $35 \%$. The least implemented step had been "devising a plan". The distinction between theoretical and practical aspects of pedagogical content knowledge is remarkable. Prospective teachers opinions about this distinction that emerged in this research were also consulted. They associated this distinction with the teacher training programmes. They stated that they had theoretical knowledge but were unable to transfer it to practice. They also criticized the teacher training programmes for not developing practical skills. At the end of this research it is thought that this problem, the difference between theoretical and practical aspects of pedagogical content knowledge of prospective teachers originates from the teacher training programs. Teacher training programs should be audited and the number of practical courses should be increased and started earlier. A more effective relationship should be established between lessons with theoretical content and practice. 